\title{
Unrecognized concomitant ventricular septal rupture and left ventricular aneurysm 10 months after myocardial infarction in a patient presenting with chronic heart failure
}

\author{
Masashi Kawamura* (1), Osamu Monta, Kana Shibata and Yasushi Tsutsumi
}

\begin{abstract}
Background: We report a rare case of concomitant inferior left ventricular aneurysm and ventricular septal rupture in a patient presenting with chronic heart failure.

Case presentation: An 81-year-old man suffered from congestive heart failure. His symptoms were alleviated by medical management; however, heart failure symptoms continued according to the New York Heart Association Functional Classification III. Ten months after presentation, ventricular septal rupture was diagnosed using echocardiography. The left ventricular aneurysm was also complicated. Surgical repair of the ventricular septal rupture and left ventricular aneurysm was successfully performed. The ventricular septal rupture consisted of multiple holes, and the infarcted myocardium had already progressed to firm, fibrotic scar tissue. We closed the ventricular septal rupture with a small bovine pericardial patch and performed an aneurysmectomy with a liner technique.
\end{abstract}

Conclusions: Cases of ventricular septal rupture can have various clinical scenarios, and treatment should be optimized for each patient, especially with respect to the timing of surgery.

Keywords: Ventricular septal rupture, Left ventricular aneurysm, Chronic heart failure

\section{Background}

Ventricular septal rupture (VSR) is a fatal mechanical complication of acute myocardial infarction (AMI). Hemodynamics usually deteriorate, and immediate treatment is needed. VSR patients who are treated medically have extremely high mortality at 30 days; however, the mortality rates of VSR remain high even when the patients are surgically managed [1]. Left ventricular aneurysm (LVA) is another fatal mechanical complication after AMI. It causes heart failure, ventricular tachycardia, and embolism. The benefits of surgical reconstruction

*Correspondence: masashi.kmura@gmail.com

Department of Cardiovascular Surgery, Fukui Cardiovascular Center,

Shinbo 2-228, Fukui City, Fukui Prefecture 910-0833, Japan for LVA have not been clearly proven [2], but their effectiveness was recently reported in selected patients [3-5]. Herein, we report a rare case of concomitant inferior left ventricular aneurysm and ventricular septal rupture in a patient presenting with chronic heart failure.

\section{Case presentation}

An 81-year-old diabetic man suffered from congestive heart failure. On admission, the electrocardiogram showed a Q wave in the III lead. Echocardiography demonstrated no apparent asynergy, and cardiac enzyme levels were not elevated. He also had epigastric pain, and coronary angiography was performed. There was significant stenosis of the right coronary artery (RCA) \#2; the patient therefore underwent percutaneous coronary 
intervention on the RCA. His symptoms were alleviated with diuretics. However, heart failure symptoms continued according to the New York Heart Association Functional Classification III. Ten months after presentation, pulmonary edema on chest X-ray scan was exacerbated (Fig. 1a) and follow-up echocardiography revealed a shunt flow of ventricular septal rupture (Fig. 1b), moderate tricuspid regurgitation, and an estimated left ventricular ejection fraction (LVEF) of 35\%. Cardiac computed tomography revealed an inferior left ventricular (LV) aneurysm (Fig. 1c). The dimensions of the LVA were $3.4 \times 4.8 \mathrm{~cm}$. Cardiac catheterization detected pulmonary high flow with an estimated Qp/Qs ratio of 3.5. Surgical treatment was indicated and the patient was referred to our hospital. The patient underwent repair of the ventricular septal rupture and liner repair of the inferior LVA. Cardiopulmonary bypass was established by ascending aorta cannulation and bicaval drainage. Intraoperatively, the VSR site was found near the apex when the inferior LVA was opened longitudinally. The VSR consisted of

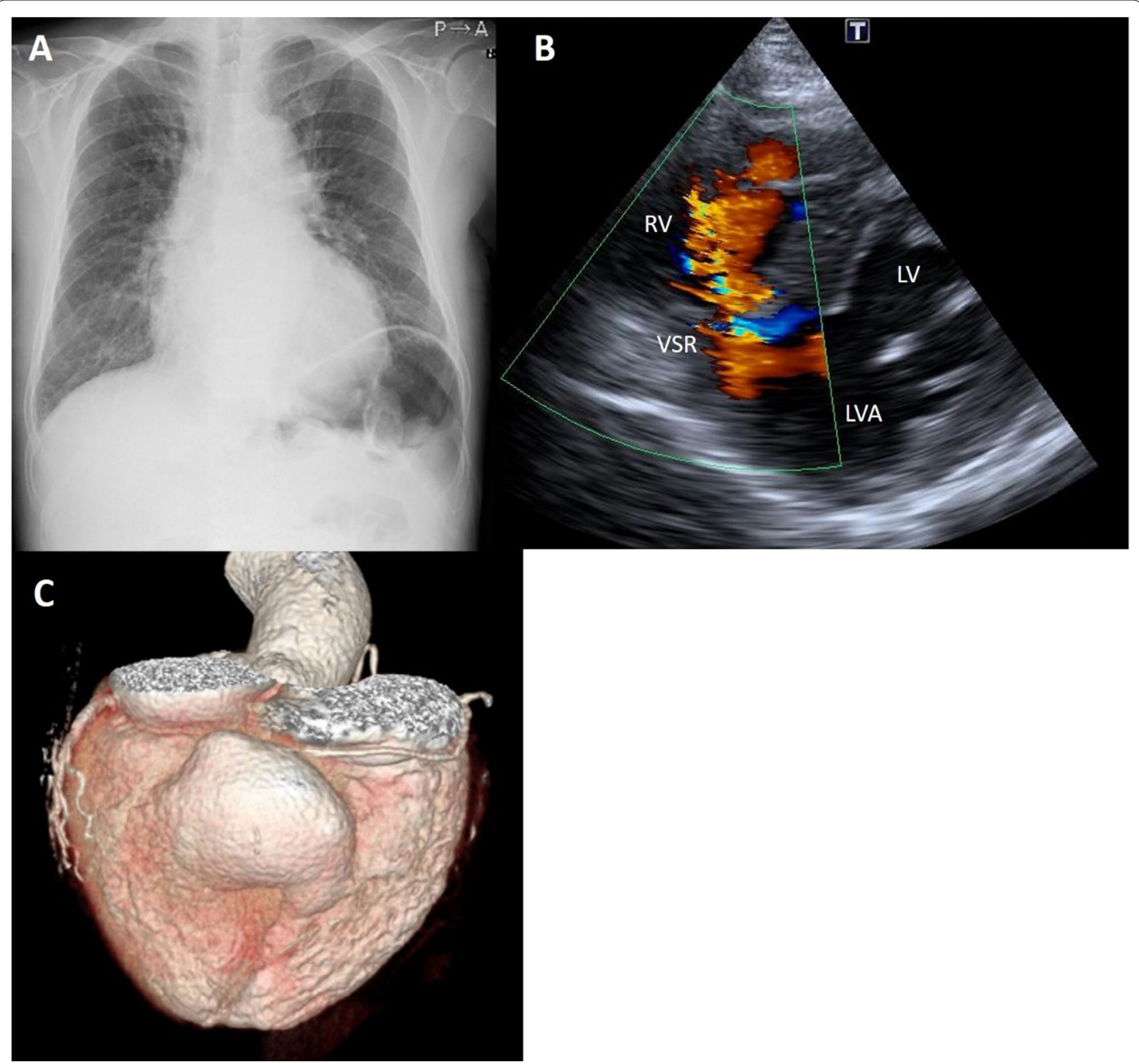

Fig. 1 a Chest radiograph showed cardiomegaly and pulmonary edema. b Echocardiography at 10 month after presentation detected left-to-right shunt. c Three dimensional volume rendering image of cardiac computed tomography revealed an inferior $L V$ aneurysm. $L V$ left ventricle, $R V$ right ventricle, LVA left ventricular aneurysm, VSR ventricular septal rupture 
multiple holes (Fig. 2a), and the infarcted myocardium had already turned to scar tissue made of firm, fibrotic tissue. The VSR was closed with a $2.5 \times 2.5 \mathrm{~cm}$ bovine pericardial patch that was fixed by 10 pairs of mattress sutures on the scar tissue around the VSR (Fig. 2b). The ventriculotomy was closed with two layers of 3-0 polypropylene mattress and running sutures with felt strips without any excision of the aneurysmal tissue. Tricuspid

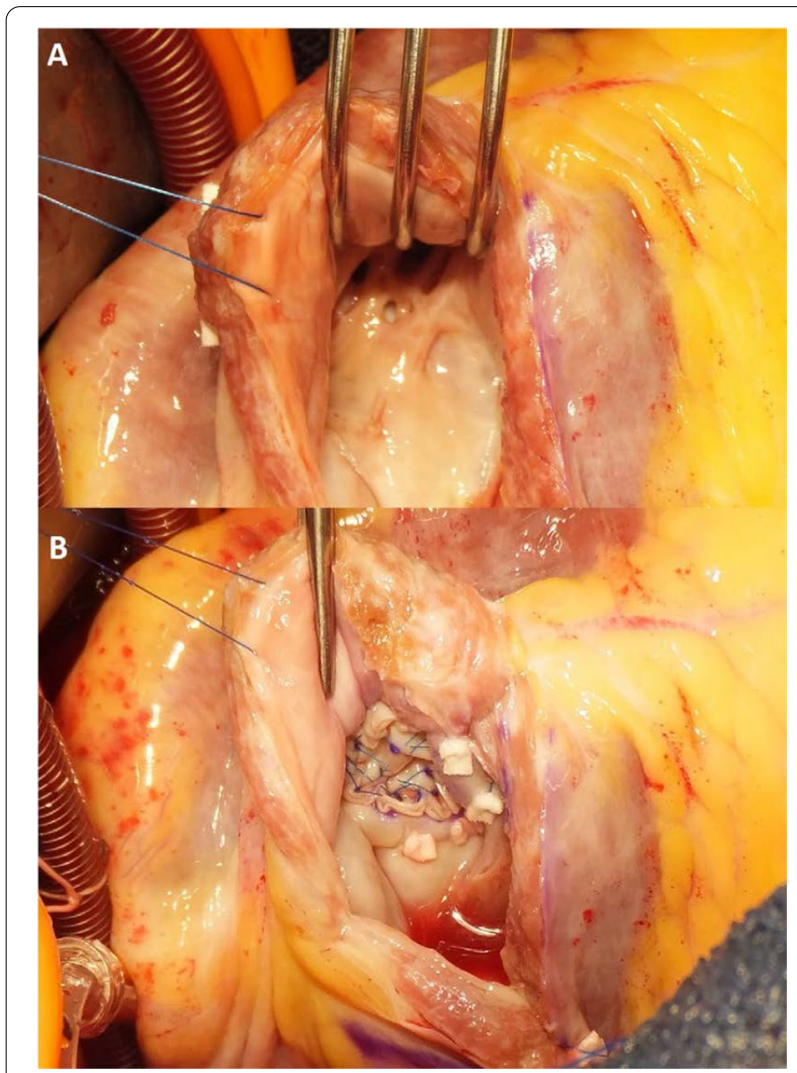

Fig. 2 a The VSR site was found near the apex. The VSR consisted of multiple holes and the infarcted myocardium already turned the scar made of firm fibrosis tissue. $\mathbf{b}$ The VSR was closed with a $2.5 \times 2.5 \mathrm{~cm}$ size of bovine pericardium patch ring annuloplasty was also performed. A residual shunt was not found on intraoperative transesophageal echocardiography. Blood transfusions were performed intraoperatively. After surgery, the patient was extubated on the first postoperative day. He needed inotropic support for 4 days and stayed in the intensive care unit for 6 days. Medical management for heart failure included only diuretics. Postoperative transthoracic echocardiography on postoperative day 10 demonstrated an LVEF of 33\% and no tricuspid regurgitation. The patient's postoperative recovery was uneventful, and he was discharged from the rehabilitation facility on the 34th postoperative day (Table 1).

\section{Discussion and conclusions}

Recent studies have demonstrated that VSR is considered to complicate $0.17-0.31 \%$ of patients presenting with AMI [6-9], and the incidence of VSR has declined due to emergent reperfusion strategies for AMI [10]. LVA is another fatal mechanical complication of AMI and the incidence of LVA has also dropped due to the same reason. Therefore, VSR and LVA, especially inferior LVA as two mechanical complications of AMI in the same patient is rare.

Liner repair [11] and endoventricular patch plasty [12, 13] are the two major procedures for surgical treatment of LVA. Previous studies have reported that there is no difference in early or late outcomes [14-17]. The selection of the technique should be based on the anatomy of the patient's aneurysm, such as its size, shape, scar dimension, and septal involvement [18]. In the present case, the LVA was relatively small. The aneurysm wall was not thin and the cavity volume was small. Therefore, we used the linear technique and obtained good results.

Our patient had a unique clinical scenario of VSR with symptoms of chronic heart failure but did not show cardiogenic shock. Some reports in the literature have demonstrated similar cases of VSR and LVA $[10,19,20]$ or VSR [21] presenting with chronic

Table 1 Timeline

\section{Timeline}

February 2020

March 2020

April-November 2020

Late-November-Early December 2020

Late December 2020

January 2021

Late April 2021
First presentation of shortness of breath

Coronary angiography revealed significant stenosis of the RCA and there was percutaneous coronary intervention for the stenosis

New York Heart Association Functional Class III on medication with diuretics

Worsening dyspnea on exertion. Pulmonary edema on chest $\mathrm{X}$-ray imaging, LVR on echocardiography, LVA on cardiac CT scan

Successful repair of the VSR and LVA

Patient discharged

3 month-follow-up by the patient's local cardiologist-no symptoms or complaints 
heart failure. The uniqueness of the present case was that the patient survived for a longer period (approximately 10 months) with VSR and LVA without surgery, whereas other cases underwent surgical repair from 3 weeks to 2 months after the initial presentation. Although VSA and/or LVA are critical, these patients obtained good postoperative outcomes. Hemodynamics in VSR patients might depend on the size and location of the VSR, in addition to the size and location of the infarction, and VSR patients can show a wide range of clinical presentations.

The timing of VSR repair remains controversial. The American College of Cardiology guidelines suggest immediate surgery for VSR, regardless of the patient's hemodynamic status [22]. In contrast, the European Society of Cardiology guidelines refer to delayed surgery in selected patients who respond to medical management [23]. Some reports demonstrated urgent or early surgery with a high mortality rate of $47-60 \%$ [24, 25], whereas delayed VSR repair after medical treatment was associated with a lower mortality rate of $15 \%$ [25]. Delayed surgery seems to be beneficial. In the present case, the occurrence of VSR was unknown. More than 10 months might have passed between the onset of myocardial infarction and surgery. The tissue around the VSR site was firm and stiff intraoperatively. We were able to stitch the scar tissue around the hole and close the hole using a small bovine pericardial patch. It was clearly technically easier than VSR repair in the acute phase. Every patient with VSR should undergo repair, while the timing of the repair should be considered based on the case of the patient, in terms of emergent surgery or elective surgery after medical optimization, etc. In addition, the percutaneous closure for VSR is becoming available and feasible, although there are some anatomical limitations, including the size, site, or shape of the VSR [26]. The percutaneous closure of the VSR in hemodynamically unstable patients as a bridge to surgery is ideal.

In conclusion, mechanical complications after AMI are rare. We encountered an extremely rare case of concomitant VSR and LV aneurysm presenting with chronic heart failure, and surgical repair of the VSR and LV aneurysm was successfully performed. VSR cases can have various clinical scenarios, and we should optimize treatment for each patient, especially with respect to timing of surgery.

\footnotetext{
Abbreviations

VSR: Ventricular septal rupture; AMI: Acute myocardial infarction; LVA: Left ventricular aneurysm; RCA: Right coronary artery; LVEF: Left ventricular ejection fraction.
}

Acknowledgements

Not applicable.

\section{Authors' contributions}

MK collected the data and wrote the manuscript. OM supervised the manuscript. YT was Chief surgeon and KS was assistant. All authors read and approved the final manuscript.

\section{Funding}

Not applicable.

\section{Availability of data and materials \\ Not applicable.}

\section{Declarations}

Ethics approval and consent to participate

Not applicable.

\section{Consent for publication}

Written informed consent was obtained from the patient for publication of this case report and any accompanying images. A copy of the written consent is available for review by the Editor of this journal.

\section{Competing interests}

The authors declare that they have no competing interests.

Received: 30 June 2021 Accepted: 3 November 2021

Published online: 17 November 2021

\section{References}

1. Jones BM, Kapadia SR, Smedira NG, Robich M, Tuzcu EM, Menon V, Krishnaswamy A. Ventricular septal rupture complicating acute myocardial infarction; a contemporary review. Eur Heart J. 2014;35(31):2060-8.

2. Jones RH, Velazquez EJ, Michler RE, Sopko G, Oh JK, O'Connor CM, Hill JA, Menicanti L, Sadowski Z, Desvigne-Nickens P, Rouleau JL, Lee KL, STICH Hypothesis 2 Investigators. Coronary bypass surgery with or without surgical ventricular reconstruction. N Engl J Med. 2009;360(17):1705-17.

3. Gensler D, Müntze J, Nordbeck P. Long-term outcome after surgical repair of a rapid-grown ischemic ventricular aneurysm causing ventricular tachycardia. Clin Case Rep. 2019;7(3):413-5.

4. Henry MJ, Preventza O, Cooley DA, de la Cruz KI, Coselli JS. Left ventricular aneurysm repair with use of a bovine pericardial patch. Tex Heart Inst J. 2014;41(4):407-10.

5. Sui Y, Teng S, Qian J, Zhao Z, Zhang Q, Wu Y. Treatment outcomes and therapeutic evaluations of patients with left ventricular aneurysm. J Int Med Res. 2019;47(1):244-51.

6. Moreyra AE, Huang MS, Wilson AC, Deng Y, Cosgrove NM, Kostis JB. Trends in incidence and mortality rates of ventricular septal rupture during acute myocardial infarction. Am J Cardiol. 2010;106:1095-100.

7. Crenshaw BS, Granger CB, Birnbaum Y, Pieper KS, Morris DC, Kleiman NS, Vahanian A, Califf RM, Topol EJ. Risk factors, angiographic patterns, and outcomes in patients with ventricular septal defect complicating acute myocardial infarction. GUSTO-I (global utilization of streptokinase and TPA for occluded coronary arteries) Trial Investigators. Circulation. 2000;101:27-32.

8. Lopez-Sendon J, Gurfinkel EP, Lopez de Sa E, Agnelli G, Gore JM, Steg $P G$, Eagle KA, Cantador JR, Fitzgerald G, Granger CB. Factors related to heart rupture in acute coronary syndromes in the global registry of acute coronary events. Eur Heart J. 2010;31:1449-56.

9. French JK, Hellkamp AS, Armstrong PW, Cohen E, Kleiman NS, O'Connor CM, Holmes DR, Hochman JS, Granger CB, Mahaffey KW. Mechanical complications after percutaneous coronary intervention in ST-elevation myocardial infarction (from APEX-AMI). Am J Cardiol. 2010;105:59-63.

10. Zhang P, Pang X, Yu D, Zhang Y. Concurrent true inferoposterior left ventricular aneurysm and ventricular septal rupture secondary to inferior myocardial infarction: a case report. Eur Heart J Case Rep. 2018;2(4):yty136. 
11. Cooley DA, Collins HA, Morris GC. Ventricular aneurysm after myocardial infarction: surgical excision with use of temporary cardiopulmonary bypass. J Am Med Assoc. 1958;167:557-60.

12. Jatene A. Left ventricular aneurysmectomy. Resection or reconstruction. J Thorac Cardiovasc Surg. 1985;89:321-31.

13. Dor V, Saab M, Coste P, Kornaszewska M, Montiglio F. Left ventricular aneurysm: a new surgical approach. J Thorac Cardiovasc Surg. 1989;37:11-9.

14. Raja SG, Salehi S, Bahrami TT. Impact of technique of left ventricular aneurysm repair on clinical outcomes: current best available evidence. J Card Surg. 2009;24:319-24.

15. Antunes PE, Silva R, de Oliveira JF, Antunes MJ. Left ventricular aneurysms: early and long-term results of two types of repair. Eur J Cardiothorac Surg. 2005:27:210-5.

16. Lange R, Guenther T, Augustin N, et al. Absent long-term benefit of patch versus linear reconstruction in left ventricular aneurysm surgery. Ann Thorac Surg. 2005:80:537-42.

17. Tavakoli R, Bettex D, Weber A, et al. Repair of postinfarction dyskinetic LV aneurysm with either linear or patch technique. Eur J Cardiothorac Surg 2002;22:129-34

18. Hui DS, Restrepo CS, Calhoon JH. Surgical decision making for left ventricular aneurysmectomy. Ann Thorac Surg. 2020;110(6):e559-61.

19. Shafi I, Oviedo C, Reddy V, Abu-Mahfouz OAE, Baciewicz FA, Afonso L. Double trouble: ventricular septal rupture (VSR) and ventricular wall aneurysm (VWA) complicating acute myocardial infarction. J Cardiovasc Dis Diagn. 2019;7:6.

20. Khanal S, Ghosh S, Mishra AK. A case report of a double catastrophe: true left ventricular aneurysm and ventricular septal rupture complicating acute myocardial infarction and presenting as chronic heart failure. Cureus. 2020;12(11):e11292.

21. Michelis I, Kontonasakis I, Tsakliadou C, Kouvelas N. Ventricular septal rupture presented with chronic heart failure symptoms: a case report. Eur Heart J Case Rep. 2019;3(2):ytz047.

22. O'Gara PT, Kushner FG, Ascheim DD, Casey DE, Chung MK, Ettinger SM, Fang JC, Fesmire FM, Franklin BA, Granger CB, Krumholz HM, Linderbaum JA, Morrow DA, Newby LK, Ornato JP, Ou N, Radford MJ, Tamis-Holland JE, Tommaso CL, Tracy CM, Woo YJ, Zhao DX, Anderson JL, Jacobs AK, Halperin JL, Albert NM, Brindis RG, Creager MA, DeMets D, Guyton RA, Hochman JS, Kovacs RJ, Kushner FG, Ohman EM, Stevenson WG, Yancy CW. 2013 ACCF/AHA guideline for the management of ST-elevation myocardial infarction: a report of the American College of Cardiology Foundation/American heart Association Task Force on practice guidelines. Circulation. 2013;127:e362-425.
23. Ibanez B, James S, Agewall S, Antunes MJ, Bucciarelli-Ducci C, Bueno H, Caforio ALP, Crea F, Goudevenos JA, Halvorsen S, Hindricks G, Kastrati A, Lenzen MJ, Prescott E, Roffi M, Valgimigli M, Varenhorst C, Vranckx P. Widimsky P, Collet JP, Kristensen SD, Aboyans V, Baumbach A, Bugiardini R, Coman IM, Delgado V, Fitzsimons D, Gaemperli O, Gershlick AH, Gielen S, Harjola V-P, Katus HA, Knuuti J, Kolh P, Leclercq C, Lip GYH, Morais J, Neskovic AN, Neumann F-J, Niessner A, Piepoli MF, Richter DJ, Shlyakhto E, Simpson IA, Steg PG, Terkelsen CJ, Thygesen K, Windecker S, Zamorano $\mathrm{JL}$, Zeymer U, Windecker S, Aboyans V, Agewall S, Barbato E, Bueno H, Coca A, Collet J-P, Coman IM, Dean V, Delgado V, Fitzsimons D, Gaemperli $O$, Hindricks G, lung B, Jüni P, Katus HA, Knuuti J, Lancellotti P, Leclercq C, McDonagh T, Piepoli MF, Ponikowski P, Richter DJ, Roffi M, Shlyakhto E, Simpson IA, Zamorano JL, Chettibi M, Hayrapetyan HG, Metzler B, Ibrahimov F, Sujayeva V, Beauloye C, Dizdarevic-Hudic L, Karamfiloff K, Skoric B, Antoniades L, Tousek P, Terkelsen PJ, Shaheen SM, Marandi T, Niemelä M, Kedev S, Gilard M, Aladashvili A, Elsaesser A, Kanakakis IG, Merkely B, Gudnason T, lakobishvili Z, Bolognese L, Berkinbayev S, Bajraktari G, Beishenkulov M, Zake I, Lamin HB, Gustiene O, Pereira B, Xuereb RG, Ztot S, Juliebø V, Legutko J, Timóteo AT, Tatu-Chitoiu G, Yakovlev A, Bertelli L, Nedeljkovic M, Studencan M, Bunc M, García de Castro AM, Petursson P, Jeger R, Mourali MS, Yildirir A, Parkhomenko A, Gale CP. 2017 ESC Guidelines for the management of acute myocardial infarction in patients presenting with ST-segment elevation. Eur Heart J. 2018;39:119-77.

24. Holmes DR Jr, Bates ER, Kleiman NS, Sadowski Z, Horgan JH, Morris DC, Califf RM, Berger PB, Topol EJ. Contemporary reperfusion therapy for cardiogenic shock: the GUSTO-I trial experience. J Am Coll Cardiol. 1995;26:668-74.

25. Arnaoutakis GJ, Zhao Y, George TJ, Sciortino CM, McCarthy PM, Conte JV. Surgical repair of ventricular septal defect after myocardial infarction: outcomes from the society of thoracic surgeons national database. Ann Thorac Surg. 2012;94:436-43.

26. Kariyanna PT, Tadayoni A, Jayarangaiah A, Hegde S, Jayaranagaiah A, McFarlane IM. Percutaneous closure of post-infarction and iatrogenic ventricular septal ruptures using amplatzer Occluder ${ }^{\circledR}$ : a systematic review. Am J Med Case Rep. 2021;9(3):184-9.

\section{Publisher's Note}

Springer Nature remains neutral with regard to jurisdictional claims in published maps and institutional affiliations.
Ready to submit your research? Choose BMC and benefit from:

- fast, convenient online submission

- thorough peer review by experienced researchers in your field

- rapid publication on acceptance

- support for research data, including large and complex data types

- gold Open Access which fosters wider collaboration and increased citations

- maximum visibility for your research: over $100 \mathrm{M}$ website views per year

At BMC, research is always in progress.

Learn more biomedcentral.com/submissions 